\title{
Nedsatt følsomhet for thyreoideahormon
}

\begin{abstract}
BAKGRUNN Ved tilstander med nedsatt følsomhet for thyreoideahormon gir ulike defekter lavere effekt av hormonet. Formålet med denne artikkelen er å gi en oversikt over slike tilstander samt oppdatert kunnskap om nedsatt følsomhet for thyreoideahormon, også kjent som thyreoideahormonresistens, med mutasjoner $\mathrm{i}$ thyreoideahormonreseptor- $\beta$ (TR $\beta$ ).
\end{abstract}

KUNNSKAPSGRUNNLAG Artikkelen er basert på et utvalg av engelskspråklige og norske originalartikler og oversiktsartikler funnet etter søk i PubMed og på forfatternes egne erfaringer med pasientgruppen.

RESULTATER Thyreoideahormonresistens har lenge vært en kjent årsak til nedsatt virkning av thyreoideahormon. Siste tiår er flere andre tilstander med nedsatt følsomhet for thyreoideahormon blitt beskrevet, og det er påvist mutasjoner i genene som koder for thyreoideahormonreseptor- $\alpha$ (TR $\alpha$ ), en cellemembrantransportør, og dejodinasene, som metaboliserer tyroksin (T4) til det bioaktive trijodtyronin (T3). Tilstandene varierer i klinisk bilde og biokjemisk profil.

FORTOLKNING Thyreoideahormonresistens kan ut fra kliniske og biokjemiske funn feiltolkes som hypertyreose, og pasientens tilstand kan bli forverret dersom den behandles som dette. Det er derfor viktig å kjenne de forskjellige sykdomsmanifestasjonene og differensialdiagnoser.

Ved tilstander med nedsatt følsomhet for thyreoideahormon, inklusive thyreoideahormonresistens, foreligger det forhøyede nivåer av hormonet uten samtidig supprimert thyreoideastimulerende hormon (TSH). Dette kan skyldes defekter i thyreoideahormonreseptorene, i selve transporten av hormonet over cellemembranene eller i den intracellulære metabolismen av hormonet. Tilstandene varierer både når det gjelder klinisk bilde og blodprøvesvar. De fleste er sjeldne, men thyreoideahormonresistens er viktig å kjenne til for å unngå overdiagnostisering og feilbehandling for antatt hypertyreose.

Thyreoideahormonresistens ble først beskrevet av Samuel Refetoff og medarbeidere i 1967 (1). Han ble oppmerksom på tre beslektede pasienter med forhøyede nivåer av thyreoideahormon i blodet, men ingen symptomer på tyreotoksikose.

I 1989 ble det genetiske grunnlaget for tilstanden kjent, da man fant en mutasjon $i$ TRß-genet (2). På 2000-tallet ble flere syndromer med nedsatt følsomhet for thyreoideahormon identifisert og flere mutasjoner i ulike gener påvist (3). I 2012 innførte man derfor et samlebegrep, «forstyrret følsomhet for thyreoideahormon», som inkluderte alle defekter med forstyrret biologisk aktivitet av kjemisk intakt thyreoideahormon utskilt $\mathrm{i}$ normal eller økt mengde (4).

\section{Kunnskapsgrunnlag}

Denne artikkelen er basert på søk i PubMed for perioden 1.1. 1990-1.11. 2014 med søkestrengen «(thyroid hormone resistance OR thyroid hormone resistance syndrome OR reduced sensitivity to thyroid hormone OR impaired sensitivity to thyroid hormone) AND (history OR etiology OR epidemiology OR symptoms OR pathogenesis OR treatment)». Søket var begrenset til engelskspråklige og norske artikler og studier gjennomført på mennesker.

Dette ga totalt 1121 artikler. Titlene ble lest og vurdert ut fra relevans - altså om artikkelen hadde tema tilknyttet thyreoideahormonresistens som en vesentlig del av innholdet. Totalt ble 182 artikler valgt ut. For disse ble sammendraget lest, og så ble 33 artikler plukket ut. Disse ble lest i fulltekst, noe som resulterte i at 26 artikler ble inkludert. Etter gjennomgang av artiklenes referanselister ble ytterligere fem artikler inkludert.

\section{Generelt}

Thyreoideahormon er nødvendig for normal utvikling og vekst hos mennesket. Hormonet regulerer cellenes basalstoffskifte ved å påvirke oksygenforbruk og varmeproduksjon (5). Nivået av thyreoideahormon i blodbanen reguleres via hypothalamus-hypofyse-thyreoidea-aksen (fig 1) $(6,7)$. For normal virkning av hormonet trengs adekvat konsentrasjon i blodet samt normale signalveier på cellenivå i målorganet.

Dette oppnås via flere steg: intakt thyreoideahormon, transport over cellemembranen, hormonaktivering gjennom intracellulær metabolisme og translokasjon inn i cellekjernen, binding til hormonreseptorer og interaksjon med koregulatorer og dermed endret uttrykk av målgener (6).

Tilstander med nedsatt følsomhet for thyreoideahormon kan inndeles i tre grupper ut fra endret funksjon av hormonreseptor, end-
Silje Agnethe Stokke Kvistad

silje.agnethe.stokke.kvistad@helse-bergen.no Hormonlaboratoriet

Haukeland universitetssykehus

\section{Paal Methlie}

Medisinsk avdeling

Haukeland universitetssykehus

Kristian Løvås

Medisinsk avdeling

Haukeland universitetssykehus

og

Klinisk institutt 2

Universitetet i Bergen

Jørn V. Sagen

Hormonlaboratoriet

Haukeland universitetssykehus

og

Klinisk institutt 2

Universitetet i Bergen

og

KG Jebsen Senter for diabetesforskning Universitetet i Bergen

\section{HOVEDBUDSKAP}

Tilstander med nedsatt følsomhet for thyreoideahormon er sjeldne

Nedsatt følsomhet for thyreoideahormon kan skyldes ulike genetiske defekter, og mutasjon i $\beta$-reseptoren er vanligste årsak

Det er viktig å kjenne til disse tilstandene for å unngå at de behandles som annen hypertyreose 
ret transport over cellemembranen, endret hormonmetabolisme (7) (tab 1).

\section{Nedsatt følsomhet på grunn av mutasjoner i TR $\beta$-reseptor Epidemiologi}

Thyreoideahormonresistens er vanligste årsak til nedsatt følsomhet for thyreoideahormon og skyldes som regel mutasjoner i $T R \beta$-genet (6). Insidensen er usikker, men har vært anslått til omtrent 1:40 $000(7,8)$. Den hittil største familien som er beskrevet $\mathrm{i}$ litteraturen er fra Vestlandet og inkluderte 36 affiserte individer (9).

\section{Etiologi og patogenese}

Mennesket har to ulike typer thyreoideahormonreseptorer, TR $\alpha$ og TR $\beta$. Disse tilhører kjernereseptorfamilien og kodes av gener lokalisert til henholdsvis kromosom 17 og kromosom 3 (10-12). De kjente mutasjonene i $T R \beta$-reseptoren fører til redusert bindingsaffinitet for T3 eller unormal interaksjon med kofaktorer (7). Fordi thyreoideahormonreseptorer kan dimerisere, kan enkelte mutasjoner i TR $\beta$-genet også påvirke friske TRproteiner, såkalt dominant negativ mutasjon.

TR $\alpha$ og TR $\beta$ er ulikt uttrykt i forskjellige vev (6). TR $\beta$ er blant annet rikt uttrykt i lever og hypofyse. I hypofysen vil nedsatt følsomhet for T3 hemme den negative tilbakekoblingen i hypothalamus-hypofysethyreoidea-aksen. Dette vil medføre en kompensatorisk stigning i TSH-nivået og dermed økt produksjon av thyreoideahormon, stimulert vekst av skjoldkjertelen og innstilling av en ny likevekt hvor nivåene av T3 og T4 i serum er forhøyet, mens TSHnivået er normalt eller lett forhøyet.

Vev med TR $\alpha$-dominans, som hjertemuskulatur, vil utsettes for disse økte nivåene av thyreoideahormon. Tilstanden arves oftest autosomalt dominant, men det er beskrevet tre familier med autosomalt recessiv arvegang (dominant negativ mutasjon) (13).

\section{Kliniske funn}

De fleste med thyreoideahormonresistens er asymptomatiske. Noen kan imidlertid ha en blanding av hypotyreose- og hypertyreosesymptomer. Det hyppigst beskrevne funnet er struma, som forekommer hos opptil $90 \%$. Sinustakykardi er også vanlig (6). En tredel av pasientene har lærevansker, og hos et fåtall har det vært rapportert lett mental retardasjon og lavt evnenivå ved formell testing (14).

Hyperaktivitet og konsentrasjonsvansker er vanlige symptomer, og studier har vist en forekomst av $\mathrm{AD} / \mathrm{HD}$ på $60-70 \%$ hos barna og på 40-50\% hos de voksne (14-16). Tilstanden er assosiert med forsinket benmodning og kortvoksthet hos barn (17), og det er også beskrevet hørselstap og økt infeksjonstendens $(14,18)$. I en norsk studie av en stor
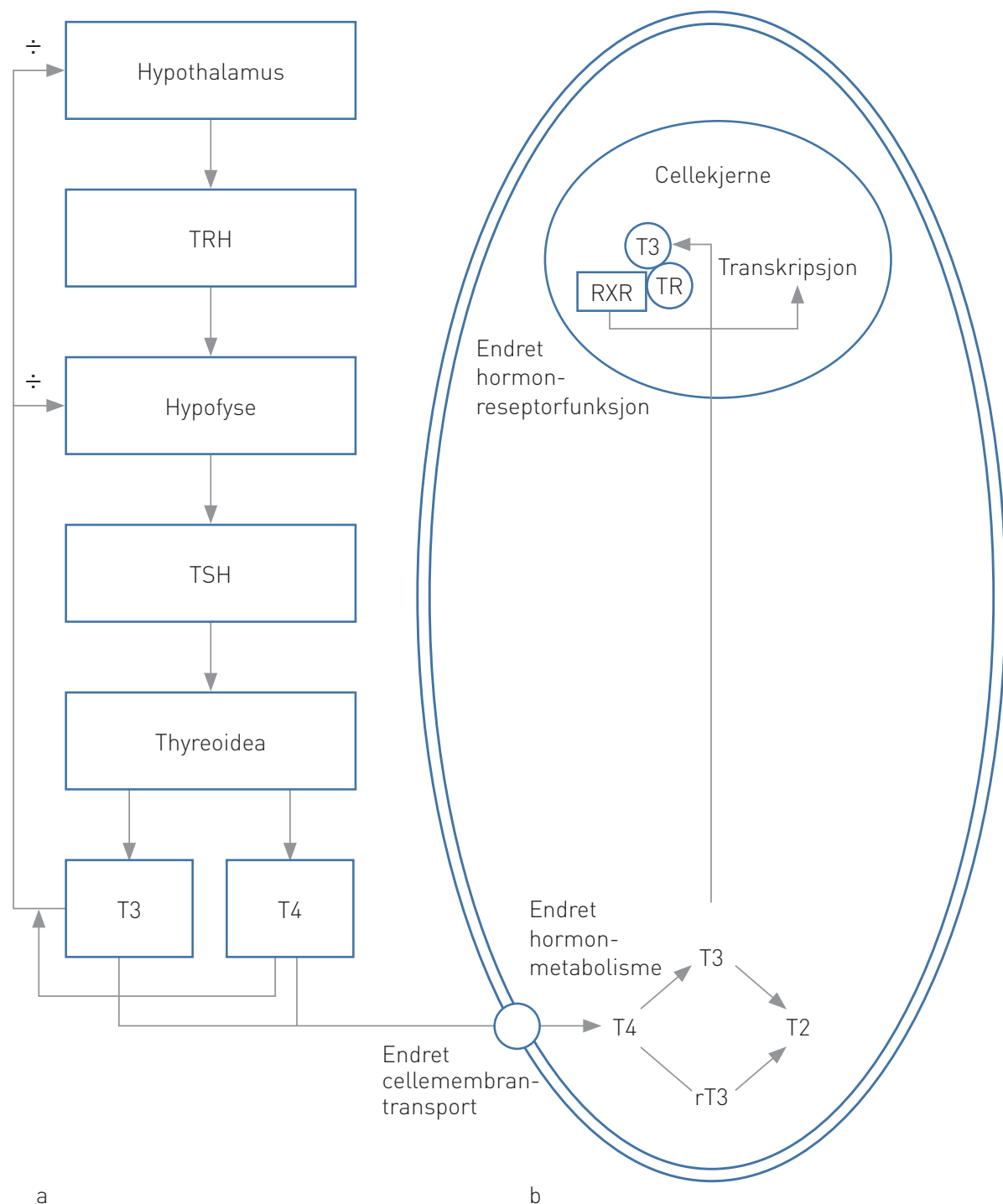

Figur 1 a) Forenklet fremstilling som illustrerer prinsippet for syntese av thyreoideahormon og negativ tilbakekobling. b) Her vises hvor i cellen de ulike defektene ved forstyrrelser $i$ thyreoideahormonsensitivitet foregår og slik gir endret effekt av hormonet (7)

familie på Vestlandet var de fleste mutasjonsbærerne asymptomatiske (9).

Tidligere ble thyreoideahormonresistens inndelt på klinisk grunnlag i generell, isolert hypofysær eller perifer vevsresistens (6). Etter påvisning av mutasjoner i TRß-genet er denne inndelingen forlatt fordi flere av undergruppene kan foreligge hos pasienter med samme mutasjon $(19,20)$.

\section{Diagnostikk}

Hos personer med thyreoideahormonresistens kan det være ulikt kliniske bilde og ulike thyreoideafunksjonsvariabler, men det foreligger som regel fire kardinaltegn (ramme 1). Laboratorieprøver viser som regel forhøyet nivå av FT4 og fritt T3 (FT3), total T4 og total T3 samt revers T3 (rT3), mens TSHnivået er normalt eller lett forhøyet. Det kan også være forhøyet serum-tyreoglobulin
(TG) som uttrykk for økt aktivitet i thyreoidea.

For primærutredning av thyreoideaforstyrrelser anbefales måling av TSH-nivå og FT4nivå. Ved prøvesvar typisk for thyreoideahor-

RAMME 1

Kardinaltegn ved nedsatt følsomhet for thyreoideahormon

- Høy serum-FT4-konsentrasjon (og vanligvis også FT3)

- Ikke supprimert (normal eller høy) serum-TSH

- Mangel på vanlige symptomer og tegn som ved hypertyreose

- Struma 
Tabell 1 Oversikt over de ulike tilstandene med nedsatt følsomhet for thyreoideahormon (5-7)

$\begin{array}{llll}\text { Etiologi Tilstand/gen } & \text { Arv } & \text { Biokjemi } & \text { Fenotype }\end{array}$

Defekt $\mathrm{i}$ thyreoideahormonvirkning

Thyreoideahormonresistens $-\beta$

Thyreoideahormonresistens- $\alpha$

Ikke-thyreoideareseptor-thyreoideahormonresistens Ukjent gen

\section{Autosomalt dominant}

Autosomalt dominant

\section{TSH: Normalt FT4: Høyt FT3: Høyt T4, T3: Høyt}

\section{TH: Lavt}

T3: Høyt rT3: Lavt
Asymptomatisk

Ev. struma, sinustakykardi Blanding av hypo- og hypertyreot symptombilde

Forsinket vekst, utvikling og benalder. Obstipasjon. Lærevansker

Lik som for thyreoideahormonresistens- $\beta$

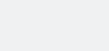

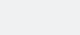

TSH: Normalt

FT4: Høyt

FT3: Høyt

T4, T3: Høyt

$\begin{array}{ll}\text { Autosomalt } & \text { TSH: Normalt } \\ \text { dominant } & \text { FT4: Høyt } \\ & \text { FT3: Høyt } \\ & \text { T4, T3: Høyt }\end{array}$

Defekt i thyreoideahormon cellemembrantransport

\begin{tabular}{|c|c|c|c|}
\hline МСТ8 & X-bundet & $\begin{array}{l}\text { T3, FT3: Høyt } \\
\text { rT3: Lavt } \\
\text { T4: Lavt/normalt }\end{array}$ & Fysisk og psykisk utviklingshemning. Ataksi \\
\hline
\end{tabular}

Defekt $i$ thyreoideahormonmetabolisme

$\begin{array}{ll}\text { Autosomalt } & \text { TSH: Høyt } \\ \text { recessiv } & \text { FT4, T4: Høyt } \\ & \text { T3: Høyt } \\ & \text { rT3: Høyt } \\ & \text { S-Se: Lavt }\end{array}$

monresistens, med høyt FT4-nivå og ikkesupprimert thyreoideastimulerende hormon, er en god anamnese med vektlegging av familiehistorie og symptomer på hyper- og hypotyreose viktig. Mistenkes thyreoideahormonresistens, anbefales det i første omgang å ta en kontrollprøve der det også måles TSH-reseptorantistoff (TRAS). Viser kontrollprøven samme resultat for TSH- og FT4nivå, bør en ny blodprøve måles med en annen analytisk metode for å utelukke heterofile antistoffer og for å redusere sannsynligheten for analytisk interferens. Spesialiserte hormonlaboratorier i Bergen og Oslo kan bidra med veiledning. Diagnosen kan bekreftes med gentesting. Dette utføres i Norge ved Hormonlaboratoriet, Oslo universitetssykehus, Aker.

Andre tilstander vil oftest kunne utelukkes ved grundig anamnese, undersøkelse av thyreoideafunksjonsvariabler og MR-undersøkelse av hypofysen (10). Det kan derimot noen ganger være vanskelig å skille thyreoideahormonresistens fra TSH-produserende hypofyseadenom. TSH $\alpha$-enhet i blodet kan måles forhøyet ved sistnevnte. Om man ikke kommer i mål, kan man gjøre Werners test, der man administrerer liotyronin (80-100 $\mu \mathrm{g}$ i $8-10$ dager). Det skal normalt gi fall i TSH-nivået. Manglende fall taler for hypofyseadenom (21).

Asymptomatiske slektninger til pasienter med påvist thyreoideahormonresistens behøver ikke utredes.

\section{Differensialdiagnoser}

Et viktig poeng er at thyreoideahormonresistens kan lede til feiltolkning av prøvesvar. Høyt FT4-nivå kan i noen tilfeller bli feilaktig oppfattet som Graves' sykdom, toksisk adenom eller toksisk knutestruma, men fravær av supprimert thyreoideastimulerende hormon bør vekke mistanke om mulig thyreoideahormonresistens, eventuelt sekundær hypertyreose. Radiojodterapi eller tyreoidektomi ved thyreoideahormonresistens mistolket som Graves' sykdom er feilbehandling (14).

Alle tilstander med forhøyet FT4-nivå med ikke-supprimert thyreoideastimulerende hormon er aktuelle differensialdiagnoser. Feil i laboratorieanalysene må utelukkes samt endrede forhold ved bindeproteiner, som ved familiær dysalbuminisk hypertyroksinemi, en arvelig tilstand hvor en mutasjon i albuminproteinet gir økt binding av tyroksin og økt serumnivå av total T4, mens FT4-nvået vil være normalt (22). Medikamentell behandling med tyroksin, amiodaron og heparin vil også kunne gi feilmålinger. Alvorlig syke pasienter vil kunne få forandringer i thyreoideafunksjonsvariabler og utgjør en mulig differensialdiagnose. Dersom slike årsaker er utelukket, foreligger det mest sannsynlig et TSH-produserende hypofyseadenom (3).

\section{Prognose og behandling}

Forløpet er varierende. De fleste forblir asymptomatiske og oppnår normal høyde som voksne, mens enkelte blir kortvokste og med lett mental retardasjon. Symptomer på hyperaktivitet avtar som regel med økende alder.

Behandling er oftest ikke nødvendig. Pasienter som plages av palpitasjoner, takykardi og tremor kan ha effekt av betablokkere (23). Noen studier har vist effekt av tyroksin eller liotyronin, fortrinnsvis til barn med forsinket utvikling og til pasienter med dominerende hypotyreosesymptomer. På grunn av ulik følsomhet for thyreoideahormon i ulike vev er det imidlertid en risiko for å indusere tyreotoksikose ved slik behandling.

\section{Nedsatt følsomhet for thyreoidea- hormon med mutasjon i TR $\alpha$}

Mutasjon i TR $\alpha$-reseptoren ble først beskrevet i 2012, og siden er flere tilfeller blitt identifisert $(19,24,25)$. Reseptoren er ikke involvert i tilbakekobling av hypothalamushypofyse-thyreoidea-aksen, og thyreoideafunksjonstestene blir dermed annerledes enn ved thyreoideahormonresistens. Det foreligger typisk høy total T3-total T4-ratio samt lav rT3, mens TSH- og FT4-nivået oftest er 
innen normalområdet. Tilstanden vil derfor ikke bli fanget opp dersom bare standardprøvene analyseres (3). Nivået av veksthormon og insulinliknende vekstfaktor 1 (IGF1) er ofte lave.

Ved genetisk utredning kan man teste for kjente mutasjoner. Det kliniske bildet domineres av veksthemning og forsinket benutvikling, obstipasjonsplager, bradykardi og mild forsinket mental utvikling. Behandling med tyroksin og veksthormon kan forsøkes. Det er beskrevet innhenting av vekst og benalder ved tyroksinbehandling i tidlig barndom samt forbedring av obstipasjonsplager og normalisering av dyslipidemi (19). På kognitive og motoriske evner er det derimot begrenset effekt av behandling (24).

\section{Nedsatt følsomhet for thyreoidea- hormon uten kjente genmutasjoner}

Noen pasienter har et nær identisk klinisk og biokjemisk bilde som ved thyreoideahormonresistens, men uten at man kan påvise mutasjon i TR $\beta$-genet. Disse klassifiseres som ikke-thyreoideareseptor-thyreoideahormonresistens og utgjør om lag $10-15 \%$ av pasientene med thyreoideahormonresistens (6). Hos disse er patogenesen usikker, men man mistenker at de har mutasjon i gener som koder for koaktivatorer eller korepressorer for thyreoideahormonreseptoren.

\section{Defekter i transporten av thyreoideahormon}

Monokarboksylasetransportør 8

(MCT8)-mutasjon

Tidligere antok man at thyreoideahormon passivt diffunderte over cellemembranen, men i 2004 ble det påvist en mutasjon i genet som koder for monokarboksylasetransportør 8 (MCT8) på X-kromosomet. Denne mutasjonen var assosiert med redusert transport av T4 over cellemembranen (25). MCT8 er en aktiv og spesifikk cellemembrantransportør for thyreoideahormon og er uttrykt i flere vev. Blant annet har den trolig stor betydning i enkelte hjernesentre og er muligens også viktig for transport over blod-hjernebarrieren (26-28).

MCT8-mutasjonene viste seg å være den genetiske basis for Allan-Dudleys syndrom. Denne tilstanden har X-bundet arvegang og et alvorlig klinisk bilde, med debut av psykomotorisk retardasjon i spedbarnsalderen (3). Pasientene har som regel alvorlig mental retardasjon, med en IQ under 40, og $25 \%$ făr epileptiske anfall (6). Laboratorieprøver viser markert forhøyet FT3- og total T3nivå, sterkt redusert rT3-nivå og en sterkt forhøyet total T3-rT3-ratio (3). Diagnosen fastsettes ved genetisk testing.

Det finnes ingen kurativ behandling. Behandling med propyltiouracil har vært forsøkt, med noe bedring på metabolske variab- ler, men uten bedring når det gjelder psykomotorisk utvikling $(26,29)$. De fleste dør i ung alder, men det er beskrevet mildere symptombilde hos noen få pasienter med restfunksjon i transportøren av thyreoideahormon (29). Feil i MCT8 er en sjelden tilstand, men interessant fordi den viser at thyreoideahormon er avhengig av transportører for effektivt å passere cellemembranen.

\section{Defekter i metabolismen av thyreoideahormon}

Mutasjon i SECIS (selenoccystein (sec) insertion sequence)-bindeprotein 2 (SBP2) Mutasjoner i $S B P 2$-genet er den hittil eneste kjente årsak til arvelig defekt i metabolismen av thyreoideahormon hos mennesket og ble første gang rapportert i 2005 (29). Den intracellulære metabolismen av thyreoideahormon reguleres av tre selenoproteinjodtyronin-dejodinaser. Aminosyren selenocystein (Sec) er nødvendig for enzymenes aktivitet (3). Mutasjonene fører til at et kodon for selenocystein ikke avleses og dejodinasene, som er selenoproteiner, fungerer ikke (30).

Insidensen er ukjent, men det er så langt beskrevet åtte familier og 14 ulike mutasjoner i $S B P 2$-genet (29). Arvegangen er autosomalt recessiv, og det er ingen kjønnsforskjell. Klinisk ser man veksthemning, mild mental og motorisk retardasjon, hørselsvansker og i noen tilfeller immunsvikt. Laboratorieprøver viser forhøyet nivå av FT4, total T4 og rT3, lavt eller normalt nivå av total T3 samt normalt eller lett forhøyet TSH-nivå (29). Diagnosen fastsettes ved genetisk testing. Det er beskrevet effekt på vekstretardasjonen ved liotyroninbehandling (31).

\section{Konklusjon}

Det finnes ulike tilstander med forstyrrelse i følsomheten for thyreoideahormon, og disse varierer både i klinikk og biokjemisk profil. Thyreoideahormonresistens er den vanligste og best karakteriserte, og det er viktig at den ikke feiltolkes og behandles som hypertyreose. Man bør kjenne til årsaker til forstyrrelse i følsomheten for thyreoideahormon for å kunne vurdere uvanlige prøvekonstellasjoner på biokjemiske variabler på thyreoideafunksjonen.

\section{Silje Agnethe Stokke Kvistad (f. 1980)}

er lege i spesialisering

Forfatter har fylt ut ICMJE-skjemaet og oppgir ingen interessekonflikter.

\section{Paal Methlie (f. 1974)}

er ph.d., spesialist i indremedisin og i endokrinologi og overlege.

Forfatter har fylt ut ICMJE-skjemaet og oppgir ingen interessekonflikter.

\section{Kristian Løvås (f. 1968)}

er spesialist $\mathrm{i}$ indremedisin og i endokrinologi, overlege og professor II. Han forsker vesentlig på binyrebarksvikt og er daglig leder for Nasjonalt Kvalitetsregister for Addisons sykdom (register for organspesifikke autoimmune sykdommer, ROAS).

Forfatter har fylt ut ICMJE-skjemaet og oppgir ingen interessekonflikter.

\section{Jørn Vegard Sagen (f. 1970)}

er dr.med., spesialist i medisinsk biokjemi og avdelingsoverlege/avdelingssjef og professor II. Han forsker på diabetesgenetikk, fedme og molekylær endokrinologi.

Forfatter har fylt ut ICMJE-skjemaet og oppgir ingen interessekonflikter.

\section{Litteratur}

1. Refetoff S, DeWind LT, DeGroot LJ. Familial syndrome combining deaf-mutism, stuppled epiphyses, goiter and abnormally high PBI: possible target organ refractoriness to thyroid hormone. J Clin Endocrinol Metab 1967; 27: 279-94.

2. Sakurai A, Takeda K, Ain K et al. Generalized resis tance to thyroid hormone associated with a mutation in the ligand-binding domain of the human thyroid hormone receptor beta. Proc Natl Acad Sci U S A 1989; 86: 8977-81.

3. Visser WE, van Mullem AA, Visser TJ et al. Different causes of reduced sensitivity to thyroid hormone: diagnosis and clinical management. Clin Endocrinol (Oxf) 2013; 79: 595-605

4. Refetoff S, Bassett JH, Beck-Peccoz P et al. Classification and proposed nomenclature for inherited defects of thyroid hormone action, cell transport, and metabolism. J Clin Endocrinol Metab 2014; 99 : 768-70.

5. Brent GA. Mechanisms of thyroid hormone action J Clin Invest 2012; 122: 3035-43.

6. Dumitrescu AM, Refetoff S. The syndromes of reduced sensitivity to thyroid hormone. Biochim Biophys Acta 2013; 1830: 3987-4003.

7. Refetoff S, Dumitrescu AM. Syndromes of reduced sensitivity to thyroid hormone: genetic defects in hormone receptors, cell transporters and deiodination. Best Pract Res Clin Endocrinol Metab 2007; 21: 277-305.

8. Lafranchi SH, Snyder DB, Sesser DE et al. Followup of newborns with elevated screening T4 concentrations. J Pediatr 2003; 143: 296-301.

9. Kvistad PH, Løvås K, Boman $\mathrm{H}$ et al. Retarded bone growth in thyroid hormone resistance. A clinical study of a large family with a novel thyroid hormone receptor mutation. Eur J Endocrinol 2004; 150: 425-30.

10. Agrawal NK, Goyal R, Rastogi A et al. Thyroid hormone resistance. Postgrad Med J 2008; 84: 473-7.

11. DeGroot LJ. Thyroid hormone nuclear receptors and their role in the metabolic action of the hormone. Biochimie 1989; 71: 269-77.

12. Yen PM. Molecular basis of resistance to thyroid hormone. Trends Endocrinol Metab 2003; 14 : 327-33.

13. Ferrara AM, Onigata $K$, Ercan $O$ et al. Homozygous thyroid hormone receptor $\beta$-gene mutations in resistance to thyroid hormone: three new cases and review of the literature. J Clin Endocrinol Metab 2012: 97: 1328-36.

14. Brucker-Davis F, Skarulis MC, Grace MB et al. Genetic and clinical features of 42 kindreds with resistance to thyroid hormone. Ann Intern Med 1995: 123: 572-83.

15. Hauser P, Soler R, Brucker-Davis F et al. Thyroid hormones correlate with symptoms of hyperactivity but not inattention in attention deficit hyperactivity disorder. Psychoneuroendocrinology 1997 22: $107-14$ 
16. Hauser P, Zametkin AJ, Martinez P et al. Attention deficit-hyperactivity disorder in people with generalized resistance to thyroid hormone. $N$ Engl J Med 1993; 328: 997-1001.

17. Sato H. Clinical features of primary hyperthyroidism caused by Graves' disease admixed with resistance to thyroid hormone (P453T). Endocr J 2010; 57: 687-92.

18. Kvistad PH. Tyreoideahormonresistens. Pediatrisk Endokrinologi 2005; 19: $52-7$.

19. Schoenmakers N, Moran C, Peeters RP et al. Resistance to thyroid hormone mediated by defective thyroid hormone receptor alpha. Biochim Biophys Acta 2013; 1830: 4004-8.

20. Onigata K, Szinnai G. Resistance to thyroid hormone. Endocr Dev 2014; 26: 118-29.

21. Macchia E, Lombardi M, Raffaelli V et al. Clinical and genetic characteristics of a large monocentric series of patients affected by thyroid hormone (Th) resistance and suggestions for differential diagnosis in patients without mutation of Th receptor $\beta$. Clin Endocrinol (Oxf) 2014; 81: 921 -8.
22. Jensen IW, Faber J. Familial dysalbuminaemic hyperthyroxinaemia: a review. J R Soc Med 1988; 81: 34-7.

23. El Shafie K, Ouhtit A, Al Farsi Y et al. A rare thyroid hormone receptor beta (THR $\beta$ ) gene mutation in a 15-year-old girl with thyroid hormone resistance syndrome: a case report. J Med Case Reports 2014; 8: 12

24. van Mullem AA, Chrysis D, Eythimiadou A et al. Clinical phenotype of a new type of thyroid hormone resistance caused by a mutation of the TR $\alpha 1$ receptor: consequences of LT4 treatment. J Clin Endocrinol Metab 2013; 98: 3029-38.

25. Bochukova E, Schoenmakers N, Agostini M et al. A mutation in the thyroid hormone receptor alpha gene. N Engl J Med 2012; 366: $243-9$.

26. Fu J, Refetoff S, Dumitrescu AM. Inherited defects of thyroid hormone-cell-membrane transport: review of recent findings. Curr Opin Endocrinol Diabetes Obes 2013; 20: 434-40.

27. Visser WE, Friesema EC, Jansen J et al. Thyroid hormone transport in and out of cells. Trends Endocrinol Metab 2008; 19: 50-6.

28. Visser TJ. Thyroid hormone transporters and resistance. Endocr Dev 2013; 24: 1-10.

29. Fu J, Dumitrescu AM. Inherited defects in thyroid hormone cell-membrane transport and metabolism. Best Pract Res Clin Endocrinol Metab 2014; 28: 189-201.

30. Dumitrescu AM, Liao XH, Abdullah MS et al. Mutations in SECISBP2 result in abnormal thyroid hormone metabolism. Nat Genet 2005; 37: 1247-52.

31. Di Cosmo C, McLellan N, Liao XH et al. Clinical and molecular characterization of a novel selenocysteine insertion sequence-binding protein 2 (SBP2) gene mutation (R128X). J Clin Endocrinol Metab 2009; 94: 4003-9.

Mottatt 19.1. 2015, første revisjon innsendt 25.8. 2015, godkjent 22.2. 2016. Redaktør: Inge Rasmus Groote. 